\title{
ФОРУМ ВСЕУКРАЇНСЬКОГО ТИЖНЯ ДОШКІЛЛЯ «ДОШКІЛЬНА ОСВІТА УКРАЇНИ 30»
}

Вітальна промова президента НАПН України, 20 вересня 2021 р., м. Київ, Україна

https://doi.org/10.37472/2707-305X-2021-3-2-16-1

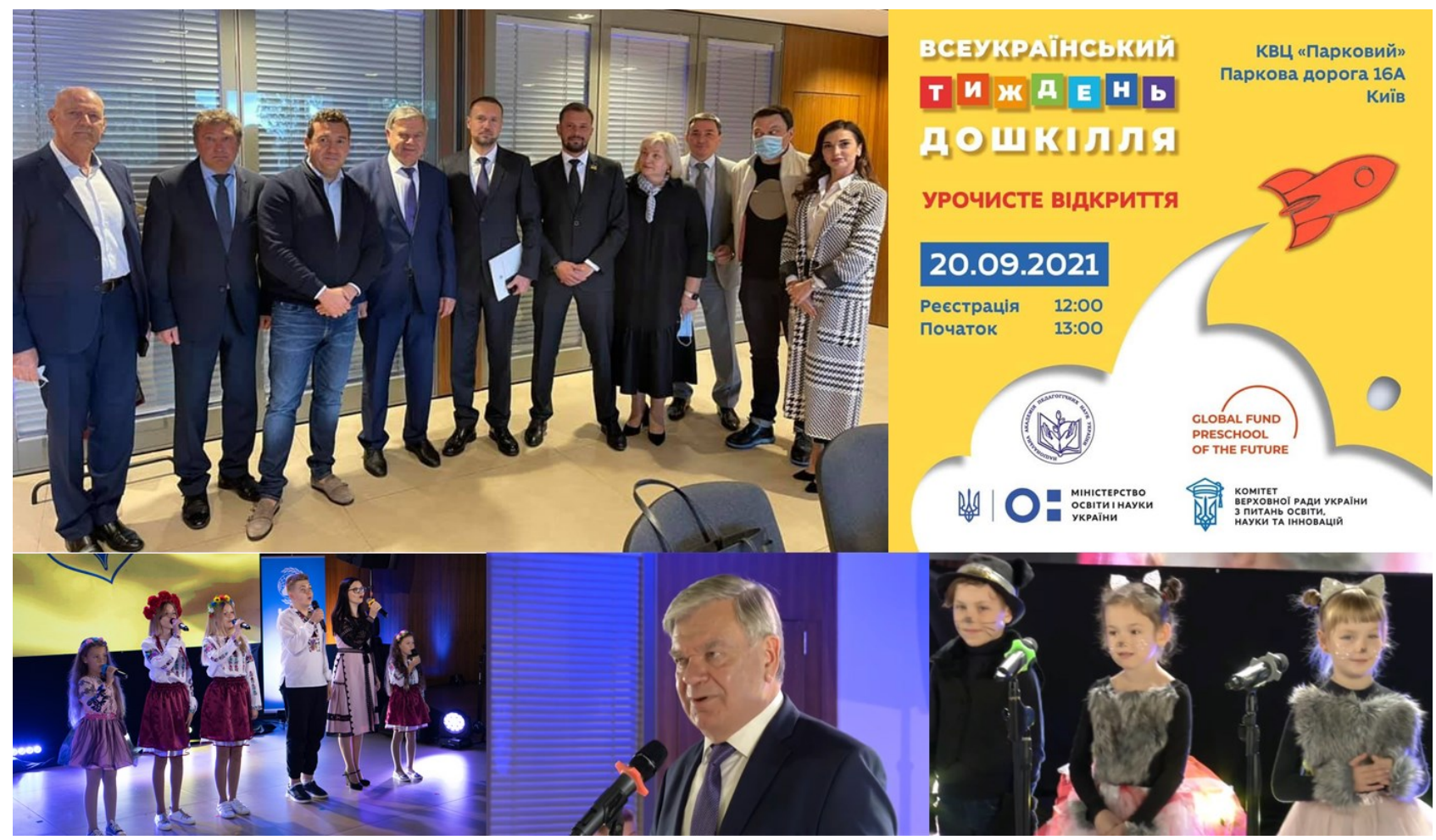

КРЕМЕНЬ Василь Григорович доктор фрілософсььких наук, профессор, дійсний член (академік) НАН України і НАПН України, президент Начіональної академії педагогічних наук України, м. Київ, Україна

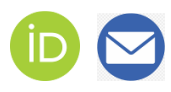

Анотація. У виступі актуалізовано проблему розвитку людини, зокрема в період дошкілля. Наведено ключові напрями, які потребують посиленої уваги: усвідомлення суспільством значимості дошкілля у житті людини; розширення мережі дошкільних закладів освіти; збільшення фінансового забезпечення тих, хто працює в дошкільній освіті; розвиток педагогічної культури батьків та підготовка молодих людей до батьківства; урахування психологічних особливостей дітей такого віку; розгортання науково-методичного забезпечення дошкільної освіти; створення єдиного досконалого центру розвитку дитини дошкільного віку, зокрема наукової установи в системі Національної академії педагогічних наук України.

Ключові слова: дошкільна освіта; ранній розвиток дитини; дошкілля; діти дошкільного віку; розвиток дитини.

Щасливе життя наших прекрасних дітей залежатиме значною мірою від того, яке в них буде дошкілля. Бо саме в цьому віці закладаються риси людини і цінності, які вона сповідуватиме все життя.

Надзвичайно приємно, що в українському суспільстві все більше цінується розвиток людини, розвиток дитини. Розвиток людини, з одного боку, це показник прогресивності будь-якого 


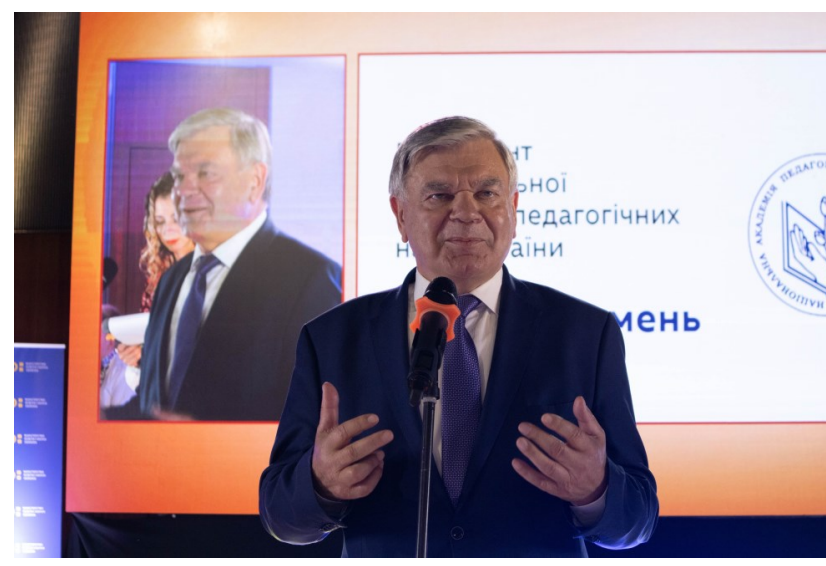

суспільства, а з іншого - розвинена людина основний важіль суспільного прогресу, особливо в час науково-інформаційних технологій.

Ми бачимо увагу в державі до освіти, що зростає, і дуже приємно, що посилюється увага до дошкілля. Це рух суспільства у правильному напрямі.

Але багато потрібно зробити в дошкіллі. 3-поміж багатьох, виокремлю лише такі ключові напрями.

Більшою мірою добитися усвідомлення суспільством значимості дошкілля у житті людини, значимості розвитку дитини в ранній і дошкільний вік.

Безумовно маємо потурбуватися про мережу дошкільних закладів освіти - державних, комунальних і приватних. Кожен знайде свою нішу.

Необхідно посилити увагу до фрінансового забезпечення тих, хто працюе в дошкільній освіті. Тільки таким чином ми зможемо залучити кращих випускників педагогічних університетів для роботи у дошкільних закладах освіти.

Дошкілля тісно пов'язане із сім'єю. Тут багато залежить від педагогічної культури батьків, а я 6 сказав, що - педагогізація суспільства, тобто надання знань і технологій, батьківству, підготовка молодих людей до батьківства - відіграє надзвичайно важливу роль.

Безумовно, науково-методичне забезпечення дошкільної освіти. Зазначу, що багато зроблено вченими Національної академії педагогічних наук України. Але в Україні має бути єдиний досконалий центр розвитку дитини дошкільного віку. У четвер було прийняте рішення про створення такої наукової установи у складі НАПН України. Я вдячний за підтримку Академії з боку Міністерства освіти і науки України, Комітету Верховної Ради України з питань освіти, науки та інновацій.

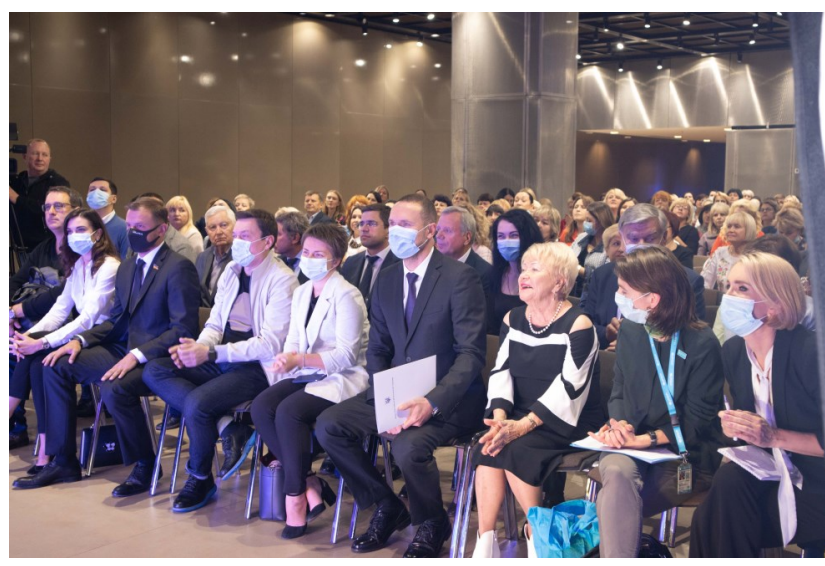

Психологія дитини нині вже інша - це має бути враховано у підручниках, програмах, вихованні тощо.

Освітяни дошкілля, ви робите святу справу! Ви дійсно забезпечуєте майбутнє України!

\section{СПИСОК ВИКОРИСТАНИХ ДЖЕРЕЛ}

Воронов, В.А., Гавриш, Н.В., Канішевська, Л.В., Піроженко, Т.О., Рейпольська, О.Д., \& Сисоєва, С.О. (Укл.). (2020). Концепція освіти дітей раннього та дошкільного віку. НАПН України. Київ. ФОП Ференець B.Б. https://bit.ly/2E3xuLJ

Канішевська, Л.В. (2021). Забезпечення якості освіти дітей раннього та дошкільного віку у приватному секторі: наука і практика. Вісник Національної академії педагогічних наук України, 3(1). https:// doi.org/10.37472/2707-305X-2021-3-1-5-5

Малиношевський, Р.В., \& Рейпольська, О.Д. (2020). Методологічний семінар Національної академії педагогічних наук України «Дошкільна освіта в контексті ідей Нової української школи». Вісник Національної академії педагогічних наук України, 2(2). https://doi.org/10.37472/2707-305X-2020-2-2-3-3

Міністерство освіти і науки України. (2021, 20 вересня). Головною метою державної політики в галузі дошкілля $\epsilon$ забезпечення доступної та якісної освіти для всіх дітей відповідного віку, - Сергій Шкарлет. https://cutt.ly/HEctHgB

Міністерство освіти і науки України. (2021, 20 вересня). Сергій Шкарлет розповів про стратегічні цілі державної політики у сфері дошкільної освіти. https://cutt.ly/REcti5v

Міністерство освіти і науки України. (2021, 20 вересня). Форум Всеукраїнського тижня дошкілля «Дошкільна освіта України 30» [Відео]. Facebook. https://www.facebook.com/UAMON/ videos/377283074008037

Національна академія педагогічних наук України. (2021, 20 вересня). Василь Кремень: "Щасливе життя наших прекрасних дітей залежатиме в значній мірі від того, яке в них буде дошкілля». http://naps.gov.ua/ua/press/releases/2423/

Президія Національної академії педагогічних наук України. (2021, 16 вересня). Про утворення Інституту раннього розвитку дитини та дошкільної освіти НАПН України (1-2/9-187). 


\section{FORUM OF THE ALL-UKRAINIAN WEEK OF PRESCHOOL EDUCATION \\ "PRESCHOOL EDUCATION IN UKRAINE 30"}

Welcome speech of the President of the National Academy of

Educational Sciences of Ukraine, September 20, 2021, Kyiv, Ukraine

Vasyl Kremen

DSc in Philosophy, Professor, Full Member (Academician) of NAS of Ukraine and NAES of Ukraine, President, National Academy of Educational Sciences of Ukraine, Kyiv, Ukraine

Abstract. The problem of human development, in particular in the preschool period, is actualized. The key directions, which need increased attention, are given: public awareness of the preschool education importance in human life, expanding the network of preschool education institutions; increasing financial security for preschool education staff; development of parents' pedagogical culture and preparing young people for parenthood; taking into account the psychological characteristics of preschool children; deployment of scientific and methodological support of preschool education; creating the only excellent center for preschool children development, in particular a research institution in the system of the National Academy of Educational Sciences of Ukraine.

Keywords: preschool education; early childhood development; preschool children; child development.

Дата публікації: 24 вересня 2021 р. 